\title{
Variability of isolated autosomal dominant GH deficiency (IGHD II): impact of the P89L GH mutation on clinical follow-up and GH secretion
}

Souzan Salemi, Shida Yousefi ${ }^{1}$, Kurt Baltensperger ${ }^{1}$, Iain C A F Robinson ${ }^{2}$, Andrée Eblé ${ }^{1}$, Dominique Simon ${ }^{3}$, Paul Czernichow ${ }^{3}$, Gerhard Binder ${ }^{4}$, Emmanuel Sonnet ${ }^{5}$ and Primus E Mullis

Paediatric Endocrinology, University Children's Hospital, Inselspital, CH-3010 Bern, Switzerland, ${ }^{1}$ Institute of Pharmacology, Friedbühlstr. 49 , 3010 Bern, Switzerland, ${ }^{2}$ National Institute for Medical Research, Mill Hill, London NW7 1AA, United Kingdom, ${ }^{3}$ Hôpital Robert Debré, Department of Paediatric Endocrinology and Diabetology, 48 Boulevard Sérurier, F-75019 Paris, France, ${ }^{4}$ University-Children's Hospital and Growth Research Centre, D-72076 Tübingen, Germany and ${ }^{5}$ Service d'Endocrinologie, CHU de Brest, Hôpital la Cavale Blanche, Boulevard, Tanguy Prigent, F-29609 Brest Cedex, France

(Correspondence should be addressed to P E Mullis; Email: primus.mullis@insel.ch)

\begin{abstract}
Objective: Four distinct familial types of isolated GH deficiency (IGHD) are classified, of which type II, IGHD II, is the autosomal dominant inherited form. Based on clinical data, it became evident that there is a wide variability in phenotype among the various $G H-1$ gene alterations leading to the disorder. As subjects suffering from IGHD II caused by the specific missense mutated P89L GH (C6129T) have never been reported in detail, the aim was to analyse the impact of this mutated $\mathrm{GH}$ form on its clinical follow-up as well as to study its effect at the cellular level in comparison with the most common missense mutation R183H GH (G6664A).

Methods: Twelve subjects belonging to four families presenting with P89L GH were clinically compared with 17 subjects from 5 families with the R183H GH missense mutation. Further, co-localization of the wild-type (wt-type) and mutant GH forms was studied in AtT-20 cells, mouse pituitary gland, applying quantitative confocal microscopy analysis. Using immunofluorescent techniques, cells were double stained for $\mathrm{GH}$ and one of the following organelles: endoplasmic reticulum (antiGrp94), Golgi (anti- $\beta C O P$ ) and secretory granules (anti-Rab3a). In addition, GH secretion and cell viability was analysed in detail.

Results: Importantly, as well as growth hormone deficiency, eight out of twelve subjects with the P89L mutated GH form developed other endocrine deficits and the pituitary gland became smaller over time $(P<0.05)$. At the cellular level, quantitative analysis of the variable mutants expressed in AtT-20 cells revealed a different extent of co-localization, different effects on GH secretion, and, therefore, a different impact on the secretory pathway which might be caused by different folding or aggregation problems necessary for sorting, packaging and/or secretion through the regulated secretory pathway. Conclusions: Our results show that specific and detailed analyses of the different mutations identified in IGHD II may shed light on the different mechanisms of secretory pathophysiology, and may provide a better explanation of the range of clinical features associated with GH missense isoforms. Importantly, the findings in patients with P89L GH extend beyond classical IGHD and stress the need for continued clinical vigilance in IGHD II patients for the development of other hormonal deficiencies.
\end{abstract}

European Journal of Endocrinology 153 791-802

\section{Introduction}

Four distinct familial types of isolated growth hormone deficiency (IGHD) have been defined on the bases of inheritance and other hormone deficiencies $(1,2)$. This classification includes IGHD type IA, autosomal recessive with absent endogenous growth hormone $(\mathrm{GH})$; type $\mathrm{IB}$, autosomal recessive with diminished $\mathrm{GH}$; type II, autosomal dominant with diminished GH; and type III, X-linked with diminished GH $(1,2)$. The autosomal dominant form of IGHD, type II (IGHD II) is most commonly caused by mutations within the first six base pairs (bp) of intervening sequences 3 (5'IVS-3) (3), which result in a missplicing at the mRNA level and the subsequent loss of exon 3, producing a 17.5-kDa human (h) GH variant (4). This GH product lacks amino acids (aa) $32-71$ (del32-71GH), which is the entire loop that connects helix 1 and helix 2 in the tertiary structure of hGH $(5,6)$. Skipping of exon 3 caused by GH-1 gene alterations other than those at the donor splice site in $5^{\prime}$ IVS-3 has also been reported in other patients with IGHD II. These include mutations in exon splice enhancer (ESE1 in exon 3 (E3)) $(\mathrm{E} 3+1 \mathrm{G} \rightarrow \mathrm{T}$, ESE1m1; E3 + 5A $\rightarrow \mathrm{G}$, ESE1m2) 
and within suggested intron splice enhancer (ISE) (IVS$3+28 \mathrm{G} \rightarrow \mathrm{A}, \quad$ ISEm1; $\quad$ IVS-3del $+28-45, \quad$ ISEm2) sequences (3, 7-12). In addition to splice site mutations that result in the production of del32-71 $\mathrm{GH}$, three other missense mutations within the $\mathrm{GH}-1$ gene cause IGHD II. These include the substitution of leucine for proline (P89L), histidine for arginine (R183H) and phenylalanine for valine (V110F) respectively $(13-16)$. Severe short stature $(<-4.5$ standard deviation score (SDS)) is not invariably present in all affected individuals (15). Binder et al. have hypothesized that children with splice site mutations may be younger and shorter at diagnosis than their counterparts with missense mutations (15). However, in a recent study of a collection of patients with different IGHD II mutations, we suggested that patients with the P89L missense mutation might be an exception, and may develop other pituitary hormone impairments similar to those reported in a specific subgroup of patients with the 17.5-kDa variant caused by exon 3 skipping induced by the $5^{\prime} \mathrm{IVS}-3+1 /+2$ bp splice site mutation (17). The $5^{\prime}$ IVS-3 $+1 /+2$ bp splice site mutation may have a greater impact on splicosome assembly and splicing efficiency than mutations more distant from the splice site (e.g. 5'IVS-3 $+5 /+6$ bp) and may, therefore, increase the exon 3 skipping. The higher quantity of $17.5-\mathrm{kDa}$ GH variant would appear to exert a dominant negative effect on packaging and secretion of 22-kDa GH, and lead to a more severe phenotype, both in vitro and in an animal model of IGHD II $(11,17-22)$. Therefore, the aim of this study was to focus specifically on the patients suffering from IGHD II caused by the P89L missense mutation, to describe their clinical follow-up and to analyse the impact of this mutation at the cellular level in terms of GH synthesis, transport, storage and secretion.

\section{Patients and methods}

\section{Patients}

In Fig. 1, three individual pedigrees as well as the growth charts of the six affected children suffering from a P89L (C6129T) missense mutation causing IGHD II are depicted. The families were of Caucasian (France), Mediterranean (Spain, Greece) and Turkish origin (Kurds) respectively. Furthermore, for comparison five additional families presenting with the most common missense mutation (R183H GH; G6664A) $(n=5$; Caucasian, France; Mediterranean, Spain, Greece; Turkish and Arab origin) were assessed and reported as a group (Table 1 ). In addition, also included in this study were affected members of families, children and adults, who had previously been diagnosed as having a missense mutation within the GH-1 gene responsible for IGHD II and who did not receive GH (nt, not treated) (Table 1). The study was approved by the Ethical Clinical Research Committee of the
University Children's Hospital, Bern, Switzerland as well as by the Ethical Committees of the collaborative Centres, and a written consent was obtained from patients and subjects. At the time of diagnosis, two independent $\mathrm{GH}$ stimulation tests were performed. The tests included an insulin tolerance test (ITT), arginine stimulation, combined arginine and ITT, clonidine and growth hormone-releasing hormone (GHRH) stimulation tests according to the guidelines as described by Ranke (23). Furthermore, adrenocorticotrophin (ACTH) reserve was tested following hypoglycaemia after ITT, and ACTH stimulation tests were performed in subjects with low basal cortisol levels (23). In addition, all the other pituitary-derived hormonal axes were assessed following identical protocols (23). Further, magnetic resonance imaging (MRI) was performed with gadolinum contrast and narrow scanning of the pituitary region.

\section{Clinical follow-up study}

Children who had been diagnosed as type II GH deficient with an identified missense mutation (P89L, $\mathrm{R} 183 \mathrm{H})$ in the GH-1 gene, and who had been treated for several years (median, 6.8 years; range, 5.5-9.6 years) with recombinant human $\mathrm{GH}(\mathrm{rhGH})$ at a regular GH replacement dose of $15-20 \mathrm{IU} / \mathrm{m}^{2} /$ week (7 injections/week) were included in this study. When near adult height $(\mathrm{AH})$ was reached, $\mathrm{GH}$ treatment was stopped for two months and the patients' pituitary hormonal axes were re-tested (see above). Near AH was defined on the basis of a height velocity of $1 \mathrm{~cm} /$ year or less over an interval of at least 6 months. Both chronological ages as well as bone age (BA) had to be at least 14 years (females) and 16 years (males). The BA was estimated according to the method of Greulich and Pyle (24). As all the subjects went through puberty normally, no sexual abnormalities were reported and basal levels of gonadotrophins and sex steroids were normal, this axis was not examined further.

\section{Hormone measurements}

Serum GH levels were measured in different clinical centres by several assays (RIA, ELISA, and enzyme immunoassay) and according to the Eilat consensus paper (Growth Research Society; GRS) a provocation peak $\mathrm{GH}$ concentration below $10 \mathrm{ng} / \mathrm{ml}$ was deemed to support a diagnosis of growth hormone deficiency (GHD) (25). Insulin-like growth factor-I (IGF-I) concentrations were determined by either an IGF-I kit (Nichols Institute Diagnostics, Bad Vilbel, Germany) or using the assays described by Blum et al. (26). Total thyroxine (TT4), free thyroxine (fT4) and thyrotrophin (TSH) were assessed on the AxSYM system (Abbott Laboratories, Abbott Park, IL, USA); using an ultrasensitive hTSH II for TSH measurements (microparticle enzyme immunoassay, MEIA). ACTH was assessed by applying 


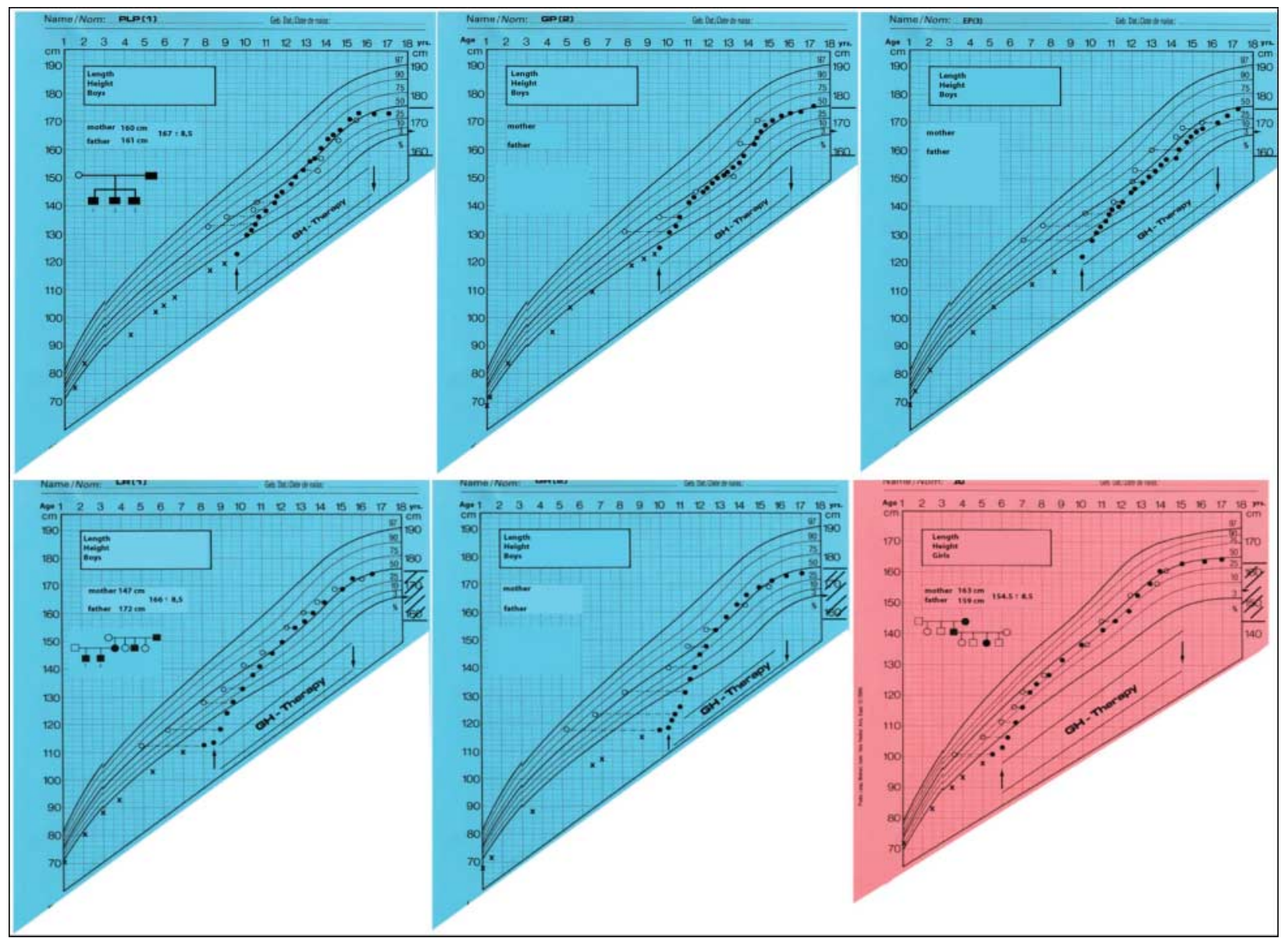

Figure 1 Growth charts of the six individuals, five boys (blue) and one girl (pink) belonging to three families. The upper row shows the three brothers of family 1 . The lower row depicts individuals from family 2 (two boys) and family 3 (one girl). The three pedigrees are presented, the time of GH treatment is outlined and the target heights according to the parental heights are stated at the right hand side of the growth charts. Open circles, bone ages (24); closed circles, height measurements. $\times$ indicates measurement by family doctor.

a sequential immunometric assay (Immulite, DPC, Los Angeles, CA, USA) and cortisol was measured using a chemiluminescence immunoassay (CLIA) (ADVIA Centauer, Bayer Corporation, Tarrytown, NY, USA).

\section{Magnetic resonance imaging (MRI)}

MRI examinations were carried out in different radiology centres as previously described in detail (17). Since the height of the pituitary gland increases with age, the data were compared with the normative data reported by Argyropoulou et al. and Tsunoda et al. (27-29).

\section{Statistical analysis}

A two samples $t$-test was performed to calculate the $P$-values. Sagittal hypophyseal height, a continuous variable, was analysed after correction for age to SDS by a 95\% confidence interval for the difference of means between the study groups (27-29).

\section{Cell culture and treatment}

Mouse pituitary (AtT-20/D16v-F2) cells were purchased from American Type Culture Collection (Manassas, VA, USA) and cultured in DMEM (Dulbecco's modified Eagle's medium, $4.5 \mathrm{~g} / \mathrm{l}$ glucose) supplemented with 10\% heat-inactivated FCS (fetal calf serum; Life Technologies, Invitrogen AG, Basel, Switzerland) and $100 \mathrm{U} / \mathrm{l}$ penicillin/streptomycin. This F2 subclone was developed from the original AtT-20 cells, an ACTH secreting cell line established from murine pituitary tumour.

\section{Expression vectors}

Wild-type GH and the naturally occurring mutants P89L GH and R183H GH were cloned in pcDNA3.1 (-) neo 
Table 1 Details of families and the patients studies with IGHD type II. Base line data are indicated in italics.

\begin{tabular}{|c|c|c|c|c|c|c|c|c|c|c|c|c|c|c|}
\hline \multirow[b]{3}{*}{ Family } & \multirow{3}{*}{$\begin{array}{l}\text { Sex } \\
M^{\text {tot }} / F^{\text {tot }}\end{array}$} & \multirow{2}{*}{\multicolumn{2}{|c|}{ Sex }} & \multicolumn{3}{|c|}{ First testing/diagnosis } & \multicolumn{8}{|c|}{ Re-assessment of adenohypophyseal function } \\
\hline & & & & \multicolumn{2}{|c|}{ Age (yrs) } & \multirow{2}{*}{$\begin{array}{l}{ }^{\dagger} \text { Peak GH } \\
\text { (mg/l) }\end{array}$} & \multirow{2}{*}{$\begin{array}{l}\text { Age at retest } \\
\text { [yrs on therapy] }\end{array}$} & \multirow{2}{*}{$\begin{array}{l}\text { Peak GHa } \\
\quad(\mathrm{mg} / \mathrm{l})\end{array}$} & \multirow{2}{*}{$\begin{array}{c}\text { IGF-I }^{\mathrm{b}} \\
(\mathrm{ng} / \mathrm{ml})[\mathrm{SDS}]\end{array}$} & \multirow{2}{*}{$\begin{array}{c}\mathrm{TSH}^{\mathrm{c}} \\
(\mathrm{mU} / \mathrm{l} ; \\
\text { no: } 0.3-5)\end{array}$} & \multirow{2}{*}{$\begin{array}{c}\mathrm{TT}^{\mathrm{c}} \\
(\mathrm{nmol} / \mathrm{l} ; \\
\text { no: } 55-135)\end{array}$} & \multirow{2}{*}{$\begin{array}{c}\mathrm{fT} 4^{\mathrm{c}} \\
(\mathrm{pmol} / \mathrm{l} \\
\text { no: } 10-20)\end{array}$} & \multirow{2}{*}{$\begin{array}{c}\mathrm{ACTH}^{\mathrm{C}} \\
\text { (ng/l; } \\
\text { no: } 9-50)\end{array}$} & \multirow{2}{*}{$\begin{array}{c}\text { Cortisol }^{\mathrm{C}} \\
(\mathrm{nmol} / / ; \\
\text { no: } 137-600)\end{array}$} \\
\hline & & $M^{t} / F^{t}$ & $M^{n t} / F^{n t}$ & $M^{t} / F^{t}$ & $\mathrm{M}^{\mathrm{nt}} / \mathrm{F}^{\mathrm{nt}}$ & & & & & & & & & \\
\hline \multicolumn{15}{|l|}{ P89L (C6129T) } \\
\hline & & $3 / 0$ & & 9.3 & & 1.5 & $16.8[6]$ & 4.0 & $150[-3.9]$ & 275 & & 18 & 19 & 452 \\
\hline & & & & 9.3 & & 2.7 & $16.8[6]$ & 3.3 & $136[-4.2]$ & 1.86 & & 17.9 & 18 & 232 \\
\hline \multirow[t]{3}{*}{$1^{*}$} & $4 / 0$ & & & 9.3 & & 2.1 & $16.8[6]$ & 3.8 & $188[-3.0]$ & 3.12 & & 17.6 & 41 & 610 \\
\hline & & & $1 / 0$ & & 48 & 1.8 & & & $50.6[-2.7]$ & 2.4 & & 15 & ND & 336 \\
\hline & & $2 / 0$ & & 8.7 & & 1.8 & $15.5[7]$ & 2.4 & $132[-4.2]$ & 1.75 & 64 & 14 & 15 & 112 \\
\hline \multirow[t]{3}{*}{$2^{*}$} & $2 / 1$ & & & 10.2 & & 2.7 & $16.2[6]$ & 1.9 & $156[-3.8]$ & 2.35 & 72 & 16 & 21 & 78 \\
\hline & & & $0 / 1$ & & 51 & 2.4 & & & $64[-2.7]$ & 1.9 & 59 & 12.2 & 13.6 & 98 \\
\hline & & $0 / 1$ & & 5.4 & & 1.9 & $15.0[9.6]$ & 2.1 & $179[-3.2]$ & 1.6 & 86 & 14.5 & 15.2 & 128 \\
\hline \multirow[t]{2}{*}{3} & $1 / 2$ & & $1 / 1$ & & 42 & 3.8 & & & $53[-3.1]$ & 1.2 & 45 & 10.1 & 32 & 294 \\
\hline & & & & & 69 & 4.1 & & & $47[-2.0]$ & 1.6 & 39 & 9.7 & 14 & 125 \\
\hline \multirow[t]{2}{*}{4} & $1 / 1$ & & $1 / 1$ & & 24 & 2.1 & & & $109[-4.9]$ & 1.5 & 41 & 8.7 & 12 & 131 \\
\hline & & & & & 47 & 1.5 & & & $42[-3.4]$ & 1.0 & 28 & 5.3 & 8 & 94 \\
\hline \multirow{2}{*}{$\begin{array}{l}n=4 \\
\text { Median (range) }\end{array}$} & $8 / 4$ & $5 / 1$ & $3 / 3$ & & & & & & & & & & & \\
\hline & & & & $\begin{array}{l}7.35 \\
(5.4-10.2)\end{array}$ & $\begin{array}{c}48.0 \\
(24-69)\end{array}$ & $\begin{array}{c}2.1 \\
(1.5-4.1)\end{array}$ & $\begin{array}{c}16.5(15-16.8) \\
{[6(6-9.6)]}\end{array}$ & $\begin{array}{c}2.85 \\
(1.9-4.0)\end{array}$ & $\begin{array}{c}108(42-188) \\
{[-3.4(-2.0 \text { to }-4.9)]}\end{array}$ & $\begin{array}{c}1.8 \\
(1.0-3.12)\end{array}$ & $\begin{array}{c}59 \\
(39-86)\end{array}$ & $\begin{array}{c}14.2 \\
(5.3-18)\end{array}$ & $\begin{array}{c}15.2 \\
(8.0-41)\end{array}$ & $\begin{array}{c}129 \\
(78-610)\end{array}$ \\
\hline \multirow{2}{*}{$\begin{array}{l}\text { R183H (G6664A) } \\
n=5 \\
\text { Median (range) }\end{array}$} & A) $11 / 6$ & $7 / 3$ & $4 / 3$ & & & & & & & & & & & \\
\hline & & & & $\begin{array}{c}7.2 \\
(4.0-13)\end{array}$ & $\begin{array}{c}48 \\
(22-69)\end{array}$ & $\begin{array}{c}2.2 \\
(0.3-4.8)\end{array}$ & $\begin{array}{l}16.9(16-17.2) \\
{[6.8(5.5-8.3)]}\end{array}$ & $\begin{array}{c}3.0 \\
(1.7-4.6)\end{array}$ & $\begin{array}{c}196(127-201) \\
{[-3.7(-2.1 \text { to }-4.5)]}\end{array}$ & $3.3(1.8-4.1)$ & $105(81-129)$ & $\begin{array}{c}14.9 \\
(12.8-19.3)\end{array}$ & $\begin{array}{c}28 \\
(15-47)\end{array}$ & $\begin{array}{c}352 \\
(221-585)\end{array}$ \\
\hline \multicolumn{15}{|c|}{ 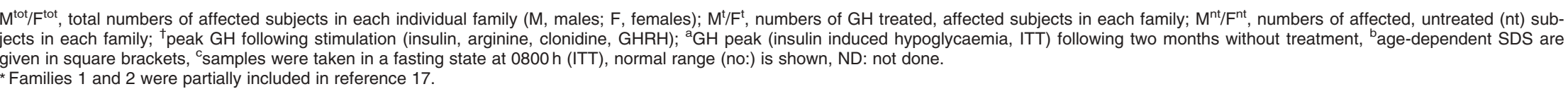 } \\
\hline
\end{tabular}


(Invitrogen, La Jolla, CA, USA) vector as described (14). AtT-20 cells were transfected with $1.5 \mu \mathrm{g}$ DNA of each vector using the FuGENE6 transfection reagent (Roche, Basel, Switzerland), followed by selection for stable clones with $300 \mu \mathrm{g} / \mathrm{ml}$ geneticin (G418; Promega Corp., Madison, WI, USA).

\section{Antibodies}

Polyclonal rabbit anti-human GH antibodies were purchased from ICN Pharmaceuticals, Inc. (Eschwege, Germany). Rat monoclonal anti-Grp94 (endoplasmic reticulum, ER) antibodies were purchased from MBL through LabForce AG (Nunningen, Switzerland).

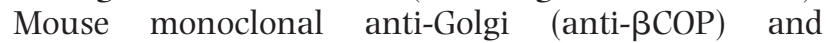
mouse monoclonal anti-Rab3a (secretory granules) antibodies were purchased from Sigma Aldrich (St Louis, MO, USA) and Synaptic Systems (Göttingen, Germany) respectively. All conjugated secondary antibodies were obtained from Jackson ImmunoResearch Laboratories, Inc. and Molecular Probes (West Grove, PA, USA).

\section{Cell preparation and immunofluorescence staining}

AtT-20 cells expressing normal or mutant GH forms were grown on slide flask Nunc delta, Article Nr. Nunc170920 (Falcon; Nalge Nunc International, Naperville, IL, USA), fixed with 4\% paraformaldehyde, and permeabilized with $0.05 \%$ Tween 20 in $2 \%$ BSA plus buffer. The cells were incubated with primary antibodies for $\mathrm{GH}$ and one of the following organelle markers. Grp94 (glucose-related proteins) belongs to a group of heat shock proteins (Hsp 90) and is one of the ER chaperones and acts as a marker for ER $(20,30)$. $\beta C O P$ is the major component of the COP-I protein complex, which is critical for vesicular traffic between the ER and Golgi, and is useful as a marker for the vesicular-tubular clusters found at the cis face of the Golgi stack, as well as the cisGolgi itself (31). Rab3a, a member of Rab protein family, belongs to the ras-related superfamily of small monomeric GTPases and is a marker for secretory vesicles (32). After washing, cells were incubated with AlexaFluor 488 (Invitrogen, La Jolla, CA, USA) conjugated secondary antibody against the GH primary antibodies and Cy3-conjugated secondary antibody against one of the cell organelles primary antibodies, for $30 \mathrm{~min}$ at $37^{\circ} \mathrm{C}$. Negative controls consisted of replacement of primary antibodies by serum. In order to make sure that AtT-20 cells were not modified by the vector transfection procedure, the staining with antibodies against markers of ER, Golgi and granules was checked before and after transfection. Confocal images of double-labelled cells were recorded using a Zeiss LSM 410 laser scanning confocal microscope. AlexaFluor 488 was excited at $488 \mathrm{~nm}$ and $\mathrm{Cy} 3$ at $517 \mathrm{~nm}$. Emission wavelengths of $510 \mathrm{~nm}$ were collected for AlexaFluor 488 and 575-640 nm for Cy3. Quantitative co-localization analysis of either normal or mutant $\mathrm{GH}$ with organelle markers was performed, using the Imaris 3.2 co-localization software module (Bitplane AG, Zürich, Switzerland). Earlier reports described a statistical means to quantify co-localization of molecules from confocal images (33). The image of each cell is scanned and fluorescent signals from the two fluorochromes are quantitated at the overlapping position. The resulting histograms display overlapping peaks of high signal intensity if the two proteins co- localize. Correlation between the fluorochromes was quantified as the Pearson correlation (1 for perfect correlation, 0 for no correlation, and -1 for inverse correlation). Average correlation coefficients of fluorescent signals from cells stimulated at different times can then be compared. The mean fluorescence intensity at different time points of 30 cells was measured for each organelle and GH. Statistical analyses were performed using ANOVA (analysis of variance) one-way test plus Dunnet's multiple comparison tests comparing each mutant to wt-GH.

\section{Forskolin stimulation}

To test for possible differences in the regulated secretion of mutant GHs compared with wt-GH, stably transfected cells were stimulated with forskolin and examined at different time points. Three different sets of experiments, each lasting for $24 \mathrm{~h}$ were performed. Stably transfected cells were seeded on slide flasks without addition of G418. After $12 \mathrm{~h}$ of growth, medium was removed from the first sets of cells. Cells were washed twice with PBS and were further incubated with DMEM plus $50 \mu \mathrm{M}$ forskolin (Sigma Aldrich) for $2 \mathrm{~h}$. After this time, the media were removed and fresh DMEM without FCS (i.e. medium free of nutrients and growth factors) was added to the cells for an additional incubation of $10 \mathrm{~h}$ to give a set of cells that were examined $12 \mathrm{~h}$ after the beginning of forskolin stimulation. This procedure was repeated with other sets of cells after $16 \mathrm{~h}$ and $20 \mathrm{~h}$ of growth to give a time point corresponding to $8 \mathrm{~h}$ and $4 \mathrm{~h}$ post-stimulation respectively. The slides were washed and fixed for immunostaining as mentioned above. Each set of experiments was repeated at least 6 times.

\section{Measurements of $\mathrm{GH}$ in the cell culture}

The amount of GH (wt-GH, R183H GH and P89L GH mutant) secreted into the cell culture supernatant was quantitatively assessed using a variety of assays as follows: hGH immunochemiluminometric assay (ICMA) (Nichols Diagnostics Institute, Bad Vilbel, Germany), GH ELISA and immuno-fucntional assay (IFA) $(34,35)$. The methods have been described previously in detail $(35,36)$. 


\section{Nucleofection and AtT-20 cell proliferation assay}

The impact of expression of the different GH mutants on AtT-20 cell viability was assessed by cell proliferation assays after transient transfection. $1 \times 10^{6}$ AtT-20 cells were nucleofected (Nucleofector, Amaxa Biosystems $\mathrm{GmbH}$, Cologne, Germany) in an electroporation cuvette along with nucleofector solution $\mathrm{R}$ and wild-type or mutant $\mathrm{GH}$ using the programme A23. Cells were transferred into fresh pre-warmed media with $10 \%$ FCS. The effect of wild-type GH or mutant GH transfection on cell viability was then assessed using a CellTiter 96 Aqueous One Solution Cell Proliferation Assay (MTS assay, Promega Corp., Madison, WI, USA) according to the manufacturer's protocol. Cells were plated in 96-well plates at $5 \times 10^{4}$ cells per well in triplicate wells and incubated for 0 to 3 days. The absorbance at $490 \mathrm{~nm}$ was recorded using a Rainbow ELISA reader (Magelan software, Tecan Company, Groedig, Austria). Transfection efficiency was checked with a control plasmid, EGFP-N1, expressing enhanced green fluorescent protein and was analysed by fluorescent microscopy. All the values obtained from 1-3 days were corrected with the background values measured after $7 \mathrm{~h}$ of nucleofection.

\section{Results}

\section{Subjects suffering from a P89L GH missense mutation}

Hormonal data In addition to all affected family members, children previously diagnosed with IGHD II were re-tested at final height (AH) following 5.5 to 9.6 years of rhGH treatment (Table 1). Although there was no difference in age at diagnosis between the P89L GH and the R183H GH group (median, 7.35 vs 7.2 years), a striking difference was found when the other pituitary gland-derived hormones were assessed either following the rhGH treatment or in the untreated adults (Table 1). No patients belonging to the R183H group presented with any pituitary-derived hormonal deficiency other than IGHD. In contrast, of twelve subjects in the P89L group, seven needed cortisol and four L-thyroxine replacements for partial ACTH (confirmed by ITT as well as by an ACTH stimulation test) and TSH deficiencies (base line data are indicated in italics on Table 1). In addition, all the adult subjects affected by the P89L GH form presented with another additional pituitary hormonal deficiency other than GHD. Furthermore, TSH and cortisol levels were statistically different between the groups, as were the total thyroxine values $(P<0.001)$.

Size of the pituitary gland In order to compare sizes of the pituitary gland and its development, patients with the P89L GH missense mutation were compared with subjects presenting with R183H GH. At diagnosis, there was no statistical difference between the pituitary heights among the patients belonging to the different groups of missense mutations (mean values: P89L, -1.3 SDS; R183H, - 1.4 SDS). As we did not have control MRI scans in all the patients, pituitary gland size was re-assessed in six randomly selected adult subjects of each group. At that time, pituitary gland sizes of the P89L GH patients were significantly smaller than those of the $\mathrm{R} 183 \mathrm{H}$ group (mean values: -2.3 SDS vs -1.7 SDS; $P<0.05$ ). Furthermore, there was a tendency towards a slight reduction of the adenohypophyseal height in patients with evolving endocrinopathy, comparing the MRI scans of patients with evolving endocrinopathy $(n=3)$ with those without $(n=3)$ (mean values: -2.5 SDS vs -2.1 SDS).

\section{Intracellular localization of either wt-GH or mutants such as R183H GH and P89L GH analysed by confocal microscopy}

Figure 2 shows expression of wt-GH, P89L GH and R183H GH when stably expressed in AtT-20 cells following $24 \mathrm{~h}$ of growth after plating. Panel I shows the overall distribution of $w t-\mathrm{GH}$ and missense mutants, with the heaviest staining in a peri-nuclear region, consistent with accumulation in the ER and Golgi complex, and in a punctuate staining near the plasma membrane, consistent with accumulation in secretory granules. This might be expected since all three proteins share the same signal peptide, but this analysis does not rule out quantitative differences in co-location. Indeed, co-staining with antibodies against markers for ER (anti-Grp94, Fig. 2A), Golgi (anti- $\beta$ COP, Fig 2B) and/or granules (anti-Rab3a, Fig 2C) began to reveal differences in the extent of subcellular co-localization. This was pursued by confocal analysis of these stably transfected cells in another set of experiments, where the cells were forskolin stimulated (forskolin stimulation assay) and stained after variable time points $(4,8$, and $12 \mathrm{~h})$ (Fig. 3). Fluorescent immunohistochemical images were recorded from single cells and the degree of co-localization with markers was calculated using Imaris co-localization software. We found a high co-localization of wt-GH with ER $(r=0.68$, 0.74 and 0.81), Golgi $(r=0.7,0.75$ and 0.81$)$ and vesicles $(r=0.8,0.79$ and 0.83$)$ after $4 \mathrm{~h}, 8 \mathrm{~h}$ and $12 \mathrm{~h}$ respectively. In contrast, $\mathrm{R} 183 \mathrm{H} \mathrm{GH}$ showed only weak association with ER $(r=0.36,0.49$ and 0.45$)$, Golgi $(r=0.53, \quad 0.29$ and 0.35$)$ and vesicles $(r=0.40,0.44$, and 0.47$)$ after $4 \mathrm{~h}, 8 \mathrm{~h}$ and $12 \mathrm{~h}$ respectively, representing a significantly $(P<0.001)$ reduced co-location in all three cell compartments compared with wt-GH. Cells expressing P89L GH also displayed a $50 \%$ reduction in co-location with the markers for ER $(r=0.33,0.29,0.58)$, Golgi $(r=0.37,0.4)$ and vesicles $(r=0.52,0.45)$ after $4 \mathrm{~h}$, 


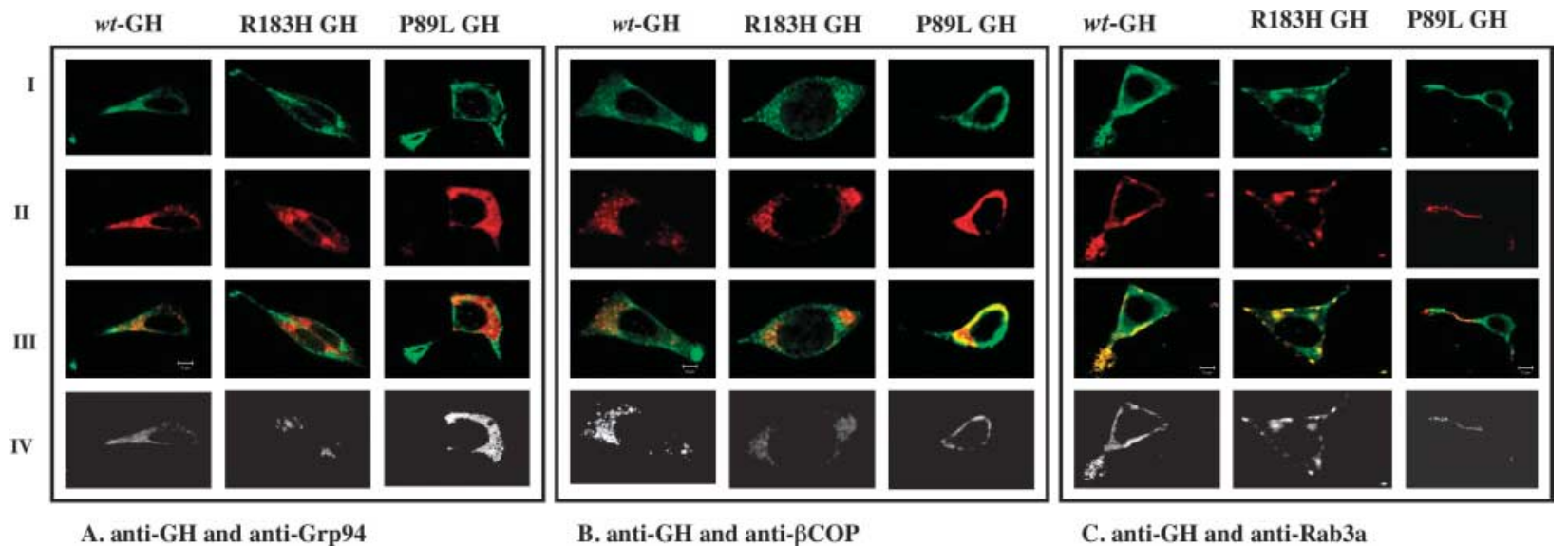

Figure 2 Subcellular co-localization of wild-type and mutant forms of GH with different organelle markers in fixed cells. (A) GH and Grp94 (endoplasmic reticulum marker) co-localization. (B) GH and $\beta C O P$ (Golgi marker). (C) GH and Rab3a (secretory granules). Row I, specific staining for wt-GH or the mutants is indicated by green colour fluorescent (FITC labelled). Row II, positive staining for cell organelles is shown by fluorescent red colour (Cy3 labelled) in the same microscopic field as in row I. Row III, merged images. Row IV, masked areas, where the intensity of the green and red fluorescence was measured in the co-localized area.

$8 \mathrm{~h}$ and $12 \mathrm{~h}$ (ER only) compared with wt-GH. However, the co-localization of P89L GH with Golgi $(r=0.65)$ and secretory vesicles $(r=0.75)$ increased significantly after $12 \mathrm{~h}$ and reached similar values as found for $w t$ $\mathrm{GH}$ transfected cells. We obtained identical results with three different stable clones of each variant. However, stable transfection selects the strong and resistant clones, so we also examined forskolin-stimulated cells after transient transfection with each mutant. The correlation coefficients of the data comparing transient versus stable transfections, ranged from 0.7 to 0.9 (not shown), suggesting that the differences we observed between the mutants were not simply due to the selection of particular stably transfected clones.
(a) $w t$-GH
(b) R183H GH
(c) P89L GH

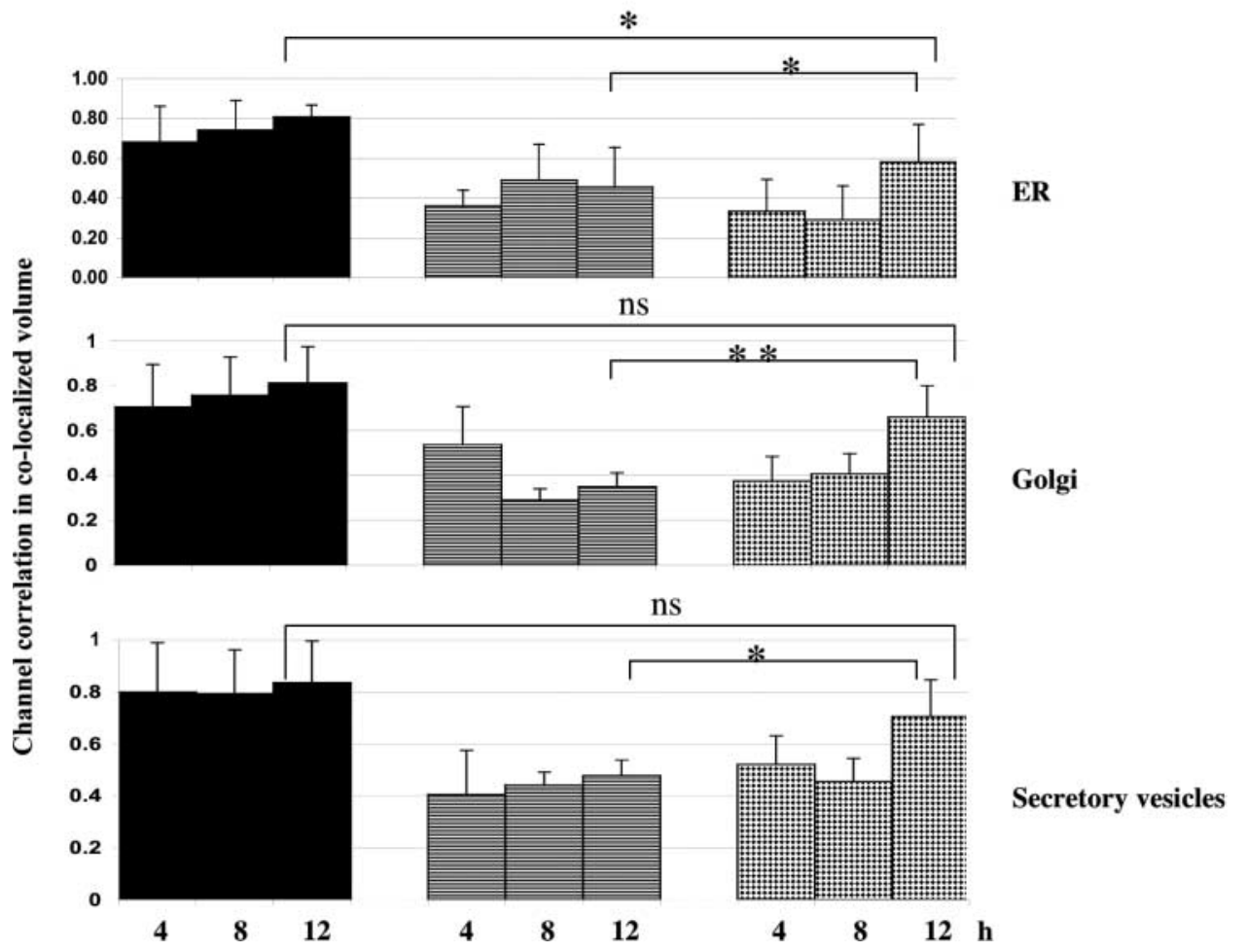

Figure 3 Quantitative analysis of confocal microscopy images. Images were obtained from the cells stimulated with forskolin at 3 different time points $(4 \mathrm{~h}, 8 \mathrm{~h}$ and $12 \mathrm{~h}$ ). Fluorescent intensities of co-localized areas were measured for $\mathrm{GH}$ or the mutants with each cell organelle. The degree of colocalization of two fluorochrome signals (GH, FITC: organelles, Cy3) was measured from a single cell (as described in the text) and average Pearson correlation coefficients are shown for 30 . AtT-20 cells expressing $w t-G H, R 183 \mathrm{H}$ GH or P89L GH mutants for each organelle. (a) Correlation between staining for $w t-G H$ and the various organelles at 4,8 and $12 \mathrm{~h}$ after stimulation. (b and c) As (a) for R183H GH and P89L GH mutant $\mathrm{GH}$ respectively. ${ }^{\star} P<0.05$, ${ }^{*} P<0.01$; ns: not significant. 


\section{Determination of GH and ACTH secretion}

In the next experiments the amount of $\mathrm{GH}$ isoforms secreted into the supernatants was determined using three different $\mathrm{GH}$ assays normalized to the same $\mathrm{GH}$ standard to control for the possibility that the mutations alter antibody binding affinity and subsequent determination of $\mathrm{GH}$ concentration in individual assays (34). The DSL ELISA (Diagnostic Systems Laboratories, San Juan, Capistrano, CA, USA) and the ICMA assays are both conventional ELISAs. The immunofunctional assay (IFA) has been developed for detection uses labelled $\mathrm{GH}$ binding protein (GHBP), which binds to binding site 1 of the human GH. Both GH mutants were detectable by all three methods and the ratios for both ELISAs (ICMA/DSL) were the same for wt-GH, R183H GH and $\mathrm{P} 89 \mathrm{~L} \mathrm{GH}$, as were the ratios of IFA/DSL and IFA/ICMA. The other assays, DSL and ICMA, showed the same ratio for both GH variants, indicating that the mutation P89L does not affect the affinity for the antibody used in these two conventional ELISAs. Thereafter, for quantification, hGH-DSL was the ELISA used for the rest of the study. Mouse ACTH concentrations were also measured as an internal control for secretion from AtT-20 cells. Here, ACTH secretion is being used as a marker for the secretory pathway in general, and not to support a specific mechanism for ACTH deficiency. As expected, the concentration of both wt-GH and ACTH increased in the supernatant with time after stimulation (Table 2). The mean values for wt-GH were found to be $5.0,8.0$ and $14.3 \mathrm{ng} / \mathrm{ml}$ after $4 \mathrm{~h}, 8 \mathrm{~h}$ and $12 \mathrm{~h}$ respectively. In contrast, $50 \%$ less $\mathrm{R} 183 \mathrm{H}$ GH was secreted (Table 2), whereas their ACTH secretion increased with time (Table 2) as in wt-GH stably transfected cells, suggesting that R183H GH has no non-specific inhibitory effect on the secretory pathway in these cells. In contrast, no P89L GH was detected in the supernatant even after $12 \mathrm{~h}$ (Table 2), although after $24 \mathrm{~h}$ a slow accumulation was noted $(1.138 \mathrm{ng} / \mathrm{ml} / 24 \mathrm{~h})$. With this mutant, however, ACTH secretion was also reduced $(11.52 \mathrm{ng} / \mathrm{ml} / 24 \mathrm{~h})$ suggesting that the P89L GH form disturbed the endogenous ACTH secretory pathway in these cells.

\section{Cell proliferation assay}

As AtT-20 cells expressing the P89L GH mutant showed reduction in both GH as well as ACTH secretion, cell proliferation was compared at $24 \mathrm{~h}$, $48 \mathrm{~h}$ and $72 \mathrm{~h}$ after transient transfection with wt-GH or missense mutants to assess their effects on cell viability. Using EGFP-N1 as a positive control, we achieved $70-80 \%$ transfection efficiency in viable AtT-20 cells. The proliferation rate of cells expressing P89L GH was equivalent to that of cells expressing wt-GH and was slightly higher than that of cells transfected with vector alone (Fig. 4). Cells expressing both missense constructs (P89L GH and R183H GH) exhibited significantly greater proliferation $(P<0.001)$ than the cells transfected with a GH construct with a splice site mutation at position $+2\left(5^{\prime}\right.$ IVS-3 $\left.+2 \mathrm{bp}\right)$ at all time points tested, and the time course of proliferation was very similar, increasing after $24 \mathrm{~h}$ and $48 \mathrm{~h}$. This increase in cell proliferation persisted for up to $72 \mathrm{~h}$ but dropped back thereafter. These experiments suggest that despite the impact of P89L GH expression on secretion, this is not simply due to a non-specific effect on cell viability or proliferation, at least under these conditions.

Table 2 Effect of forskolin stimulation of GH and ACTH secretion at different time points from stable AtT-20 cells expressing wt-GH or one of the mutants. The mean values \pm S.E.M. of 6 independent experiments are shown.

\begin{tabular}{|c|c|c|c|c|c|c|c|}
\hline & \multirow[b]{2}{*}{ GH $(\mathrm{ng} / \mathrm{ml})$} & \multicolumn{2}{|c|}{$\Delta$ increase GH } & \multirow[b]{2}{*}{ АСТH (ng/ml) } & \multicolumn{2}{|c|}{$\Delta$ increase ACTH } & \multirow[b]{2}{*}{ GH/ACTH (secretion index) } \\
\hline & & $\mathrm{ng} / \mathrm{ml}$ & $\%$ & & $\mathrm{ng} / \mathrm{ml}$ & $\%$ & \\
\hline \multicolumn{8}{|l|}{$w t-\mathrm{GH}$} \\
\hline $4 \mathrm{~h}$ & $5.0 \pm 2.8$ & & 100 & $14.94 \pm 4.2$ & & 100 & 1 \\
\hline $8 \mathrm{~h}$ & $8.0 \pm 4.5$ & 3.0 & 160 & $26.8 \pm 8.9$ & 11.86 & 179 & 0.89 \\
\hline $12 \mathrm{~h}$ & $14.3 \pm 5.7$ & 9.3 & 286 & $35.7 \pm 13.2$ & 20.76 & 239 & 1.19 \\
\hline \multicolumn{8}{|c|}{$\mathrm{R} 183 \mathrm{H}$ GH } \\
\hline $4 \mathrm{~h}$ & $2.8 \pm 0.92$ & & 100 & $19.43 \pm 12.1$ & & 100 & 1 \\
\hline $8 \mathrm{~h}$ & $5.5 \pm 1.5$ & 2.7 & 196.4 & $26.0 \pm 15.9$ & 6.57 & 134 & 1.46 \\
\hline $12 \mathrm{~h}$ & $7.9 \pm 0.9$ & 5.1 & 282.1 & $34.34 \pm 20$ & 14.91 & 176.7 & 1.59 \\
\hline \multicolumn{8}{|c|}{ P89L GH } \\
\hline $4 \mathrm{~h}$ & $0.007^{*}$ & 0 & & $6.48 \pm 0.9$ & & 100 & 0 \\
\hline $8 \mathrm{~h}$ & $0.014^{*}$ & 0.007 & & $10.0 \pm 2.3$ & 3.52 & 154.3 & 0 \\
\hline $12 \mathrm{~h}$ & $0.0128^{\star}$ & 0.0058 & & $10.91 \pm 0.9$ & 4.43 & 168.4 & 0 \\
\hline $24 \mathrm{~h}$ & $1.138^{*}$ & 1.131 & & $11.52 \pm 0.9$ & 5.04 & 177.8 & 0.1 \\
\hline
\end{tabular}

The secretion index is calculated as concentration GH/concentration ACTH in the supernatant (37). R183H GH showed a $50 \%$ reduction in GH release compared with $w t-G H$, but the secretion index remained close to 1 . In contrast, cells expressing P89L GH showed a significant reduction in GH release after $12 \mathrm{~h}$, but small amounts of $\mathrm{GH}$ were released after $24 \mathrm{~h}(1.338 \mathrm{ng} / \mathrm{ml} / 24 \mathrm{~h})$. ${ }^{*} P<0.01$ compared with corresponding values for wt-GH using a Mann-Whitney test. 


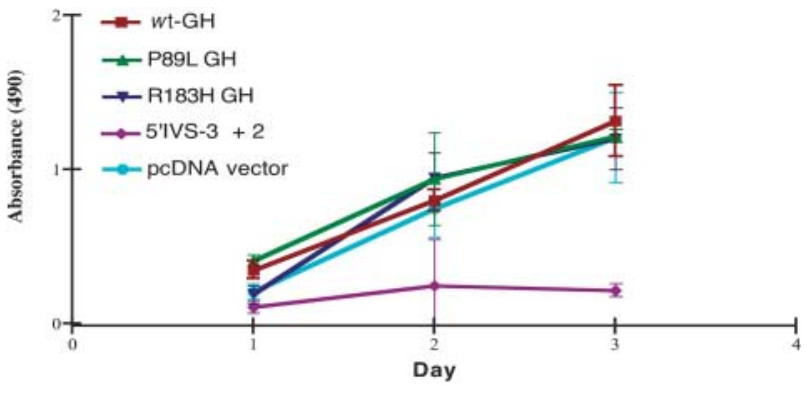

Figure 4 Cell proliferation was assessed using the MTS assay. AtT-20 cells transiently transfected with either $w t$ - or the mutants P89L GH, R183H GH, 5'IVS-3 + 2 and empty pcDNA vector as control. Proliferation was estimated at 24,48 and $72 \mathrm{~h}$ transfection. The proliferation rate of cells expressing P89L GH, wt-GH and $\mathrm{R} 183 \mathrm{H} \mathrm{GH}$ were equivalent, slightly higher than that of cells transfected with empty vector, and significantly $(P<0.001)$ higher than in cells transfected with the GH splice site mutation ( $5^{\prime}$ IVS-3 +2 ) at all time points tested. Results are expressed as mean optical density of 6 independent experiments in triplicate (means \pm S.E.M.).

\section{Discussion}

It has been suggested that children with splice site mutations in their GH-1 gene may be younger and shorter at diagnosis than their counterparts with missense mutations (15). However, when various mutations were analysed in detail $(3,7-15)$, it became clear that this generalization did not hold true for patients presenting either the C6129T missense mutation yielding P89L GH, or the $5^{\prime}$ IVS-3 $+5 /+6$ bp splice site mutations leading to the exon 3 skipped $17.5-\mathrm{kDa}$ form of $\mathrm{GH}$. Furthermore, we recently reported that subjects with $5^{\prime}$ IVS- $3+1 /+2$ bp splice site mutations skipping exon 3 are not only more severely GHD but may eventually present with other pituitary hormone deficiencies, unlike the patients with IGHD II caused by $5^{\prime}$ IVS-3 $+5 /+6$ bp splice site mutations (17). There were two aims of the present study. One was to evaluate in more detail the possible additional endocrine deficits in four families with the missense P89L GH mutation compared with subjects with the R183H GH mutation causing IGHD II. The other was to compare the cellular effects of this and other dominant IGHD II missense mutations when expressed in a model endocrine cell line in vitro.

\section{Clinical course of IGHD II in subjects expressing P89L GH}

Compared with patients with IGHD II caused by splice site mutations leading to a skipping of exon 3 (median age at diagnosis, 3 years) (17), patients with P89L GH were rather older (median age, 7.35 years) when GHD was diagnosed by their caring physician (mean height velocity, $2.7 \mathrm{~cm} /$ year; -5.8 SDS). Although this time of primary diagnosis was comparable with that in subjects presenting with R183H GH missense mutations (7.2 years median) and much later than in subjects with splice site mutations, examination of their growth charts revealed that subjects with P89L GH were falling off the centiles much earlier (Fig. 1). Their response to GH replacement therapy $\left(15-20 \mathrm{IU} / \mathrm{m}^{2} /\right.$ week $)$ would be judged as good as all subjects surpassed their estimated parental target heights. However, we interpret this result with caution as in an autosomal dominant growth disorder one parental height may well be compromised. The most striking difference noted in patients with P89L GH is the longer-term impact on other pituitary hormonal axes. Out of twelve subjects, eight were partially ACTH and/or TSH deficient either at the median age of 16.5 years following $\mathrm{GH}$ replacement therapy $(n=3)$ or in all but one untreated affected adult family members at the median adult age of 47 years $(n=5)$. This contrasts markedly with data from 17 patients with IGHD II caused by the $\mathrm{R} 183 \mathrm{H}$ missense mutated $\mathrm{GH}$ form (Table 1). In addition to endocrine deficits, pituitary hypoplasia also developed in subjects with P89L GH. Although at the beginning no differences in pituitary sizes assessed by MRI scans between the various forms of IGHD II were found, at the time of re-evaluation, the pituitary gland sizes of P89L GH affected subjects were significantly smaller when compared with the normative data reported by Tsunoda et al. (29). The combination of severity of phenotype, pituitary hypoplasia and incidence of pituitary endocrine deficits of the most severe splice site mutations is shared by this particular P89L missense mutation.

\section{Analysis of the P89L GH variant at the cellular level}

Intracellular co-localization To look for differences in effects of missense mutations, we performed co-localization analysis of wt-GH, R183H GH or P89L GH stably transfected into a suitable endocrine cell line, using organelle markers with or without stimulation of secretion with forskolin. To avoid the complication of interactions with endogenous GH, we used AtT20 cells whose endogenous ACTH production and secretion could be followed as an internal control. Costaining with antibodies against $\mathrm{GH}$ and either antiGrp94 (ER), anti- $\beta$ COP (Golgi) or anti-Rab3a (vesicles) revealed that wt-GH and both $\mathrm{R} 183 \mathrm{H} \mathrm{GH}$ and P89L GH mutants presented different subcellular co-localization patterns. At $4 \mathrm{~h}$ and $8 \mathrm{~h}$ after forskolin treatment, an overall reduction of co-localization in all the compartments studied of about 50\% was found for both mutants (R183H GH, P89L GH) compared with the wt-GH transfected cells. However, by $12 \mathrm{~h}$, we observed a significant increase of co-localization of P89L GH (but not $\mathrm{R} 183 \mathrm{H} \mathrm{GH}$ ) with Golgi as well as secretory vesicle markers, to reach values similar to those for wt-GH. This suggests that even if misfolded and with some delay, P89L can enter the secretory vesicle pathway. 
GH secreted into the supernatant We used various methods to measure the variable $\mathrm{GH}$ forms since most assays are characterized for the detection of 22-kDa GH and their cross reactivities to mutant $\mathrm{GH}$ proteins are uncertain (34). This important fact was analysed and it has to be stressed that P89L GH and R183H GH expressed alone were reproducibly detectable by DSLELISA, ICMA and IFA in a clear and dose-dependent manner. In agreement with the co-localization data, R183H GH secretion into the supernatant was reduced by around $50 \%$ compared with wt-GH, whereas endogenous ACTH secretion remained stable, suggesting that this mutation affects $\mathrm{GH}$ production but does not compromise the secretory pathway in general. In contrast, no P89L GH was secreted over $12 \mathrm{~h}$, and ACTH release was also drastically reduced, suggesting that the presence of this form of $\mathrm{GH}$ had a more general effect on the secretory activity of the cell. With extended time of analysis, a slight increase in P89L GH was observed. This could imply that the secretory block was overcome, but could also reflect leakage or overflow into constitutive secretory pathways when the regulated pathway was compromised. These data emphasize that simply finding P89L GH accumulating in secretory vesicles by colocalization, does not imply that these organelles are competent to release this cargo.

\section{Possible mechanism and clinical impact}

Taken together, our data suggest that the two missense GH mutants have different impacts on secretion in endocrine cells. Both may be misfolded in different ways and neither is as efficiently processed as wt-GH.

The R183H GH mutant shows reduced synthesis and secretion, but does not affect ACTH release, implying a specific impact on vesicles carrying a GH cargo, but not affecting packaging and release of other secreted proteins. We have previously shown in an individual with the R183H mutation that $\mathrm{GH}$ is stored, but its release is severely impaired (37). It is thus possible that $\mathrm{R} 183 \mathrm{H} \mathrm{GH}$ aggregates are processed and packaged, but interfere with wt-GH, so that fewer secretory granules are produced, and/or they are exocytosed less efficiently (38). The P89L GH has a much more profound effect, with almost no secretion for long periods following expression, which compromised the secretion of cargo unrelated to $\mathrm{GH}$, implying a much more profound disturbance early in the secretory pathway or the ER. Eventually, some P89L GH does reach vesicular structures, but its secretion from this compartment increases gradually and may not be able to participate in normal pulsatile $\mathrm{GH}$ release from the regulated secretory compartment. Its effect on secretion of other proteins, even in the absence of co-expression of wt$\mathrm{GH}$ implies that P89L GH has a more damaging effect on protein secretion. There is a conserved proline residue in the second alpha-helix of many GH proteins, corresponding to proline 89 in human GH (16). This residue is not directly involved in contact with GH receptors, and since it compromises ACTH release in the absence of $w t-\mathrm{GH}$, it does not require mis-dimerization with wt-GH to generate its inhibitory effects. Proline 89 disfavours alpha-helix formation and bends the second GH helix towards the other alphahelices (5). It is thus reasonable to speculate that substitution of proline by leucine would alter the orientation of these helices. $\mathrm{GH}$ is the major protein product of the somatotroph, so if this P89L mutation induces a strong misfolded protein response in the ER, it could explain why traffic of other proteins, specifically of $w t-\mathrm{GH}$ derived from the unaffected allele, through the secretory pathway is also affected as we have shown for ACTH in the AtT-20 cells. The lag in accumulation and secretion of P89L GH could reflect an increase in the time it takes to fold and package this mutant molecule to leave the ER (39). However, this does not immediately impact on the viability of the cell, since after transient transfection of AtT-20 cells, proliferation rates in cells expressing missense mutants were equivalent to those in cells expressing the $w t-G H$, whereas proliferation was significantly slower in cells transfected with a $5^{\prime}$ IVS-3 +2 bp exon 3 skipped 17.5-kDa GH.

Combining our present results with those from earlier studies, we conclude that a single mechanism alone cannot account for dominant inhibition of wt-GH secretion by the different reported mutations, impacting early vs late in the secretory pathway, having specific vs non-specific effects on other secreted proteins, and affecting GH cells only, or involving several other cell types in vivo (37-49). Since the expression of the $G H$ gene in the pituitary is strongly restricted to the somatotroph/lactotroph lineage, the effects on other cell types e.g. thyrotrophs (18) is unlikely to be caused by misexpression of naturally occurring P89L GH in these cells, but rather to secondary events occurring in vivo. These could involve release of cytokines within the pituitary from somatotrophs, surrounding folliculostellate cells, or from activated macrophages clearing debris from autolysing somatotrophs and causing bystander damage. McGuinnness et al. (18) reported that the most severely affected mice expressing del32-71GH mutant and showing multiple pituitary deficits had massive macrophage infiltration in the pituitary gland. The extent of bystander cell damage probably depends on the severity, specificity and rapidity of the somatotroph cytotoxicity induced by different mutations, and might explain the difference between P89L (severe, non-specific effects) and other missense mutants (milder specific inhibition of GH secretion), both short term in vitro, and in our patients. Since in both mice and patients additional pituitary hormonal deficiencies may also develop with time, with or without GH replacement therapy, the clinical importance of maintaining vigilance for these is underscored by these studies. A more detailed followup of patients with different IGHD II mutations may 
give new information on the impact of misfolded proteins in secretory pathways in other endocrine cell types and syndromes of autosomal dominant hormone deficiencies.

\section{Acknowledgements}

Family 1 presenting with the missense P89L GH form was analysed at the molecular level by Prof. Serge Amselem, INSERM U468, Hôpital Henre Mondor, Créteil, France, as was one family belonging to the R183H GH group. In addition, we are very grateful to Prof. Jürg Girard, Basel, for measuring ACTH. The study was supported by a grant of the Swiss National Science Foundation to P E M (SNF 3200-064623.01).

\section{References}

1 Phillips JA III. Inherited defects in growth hormone synthesis and action. In The Metabolic and Molecular Bases of Inherited Disease, edn 7, pp 3023-3044. Eds CR Scriver, AL Beaudet, WS Sly \& D Valle. New York: McGraw-Hill, vol II, 1995.

2 Rosenfeld RG \& Cohen P. Disorders of growth hormone/insulin-like growth factor secretion and action. In Pediatric Endocrinology, edn 2, pp 211-288. Ed. M Sperling. Philadelphia: Saunders, 2002.

3 Mullis PE, Deladoëy J \& Dannies PS. Molecular and cellular basis of isolated dominant-negative growth hormone deficiency, IGHD type II: insights on the secretory pathway of peptide hormones. Hormone Research 200258 53-66.

4 Binder G \& Ranke MB. Screening for growth hormone (GH) gene splice-site mutations in sporadic cases with severe isolated GH deficiency using ectopic transcript analysis. Journal of Clinical Endocrinology and Metabolism 199580 1247-1252.

5 de Vos AM, Ultsch M \& Kossiakoff AA. Human growth hormone and extracellular domain of its receptor: crystal structure of the complex. Science 1992255 306-312.

6 Cunningham BC, Ultsch M, de Vos AM, Mulkerrin MG, Clauser KR \& Wells JA. Dimerization of the extracellular domain of the human growth hormone receptor by a single hormone molecule. Science $1991254821-825$.

7 Takahashi I, Takahashi T, Komatsu M, Sato T \& Takada G. An exonic mutation of the GH-1 gene causing familial isolated growth hormone deficiency type II. Clinical Genetics $200261222-225$.

8 Cogan J, Ramel B, Lehto M, Phillips JA III, Prince M, Blizzard R, de Ravel T, Brammert M \& Groop L. A recurring dominant negative mutation causes autosomal dominant growth hormone deficiency - a clinical research center study. Journal of Clinical Endocrinology and Metabolism 199580 3591-3595.

9 Moseley C, Mullis P, Prince M \& Phillips JA III. An exon splice enhancer mutation causes autosomal dominant GH deficiency. Journal of Clinical Endocrinology and Metabolism 200287 847-852.

10 Cogan J, Prince M, Lekhakula S, Bundey S, Futrakul A, McCarthy E \& Phillips JA III. A novel mechanism of aberrant pre-mRNA splicing in humans. Human Molecular Genetics 1997 6 909-912.

11 Ryther RC, McGuinness LM, Phillips JA III, Moseley CT, Magoulas CB, Robinson IC \& Patton JG. Disruption of exon definition produces a dominant-negative growth hormone isoform that causes somatotroph death and IGHD II. Human Genetics 2003113 140-148.

12 McCarthy EMS \& Phillips JA III. Characterization of an intron splice enhancer that regulates alternative splicing of human $\mathrm{GH}$ pre-mRNA. Human Molecular Genetics 19987 1491-1496.

13 Duquesnoy P, Simon D, Netchine I, Dastot F, Sobrier ML, Goossens M, Czernichow P \& Amselem S. Familial isolated growth hormone deficiency with slight height reduction due to a heterozygote mutation in GH gene. In Program of the 80th Annual meeting of The Endocrine Society, pp P2-202. New Orleans, LA, 1998.

14 Deladoëy J, Stocker P \& Mullis PE. Autosomal dominant GH deficiency due to an Arg183His GH-1 gene mutation: clinical and molecular evidence of impaired regulated GH secretion. Journal of Clinical Endocrinology and Metabolism 200186 3941-3947.

15 Binder G, Keller E, Mix M, Massa GG, Stokvis-Brantsma WH, Wit JM \& Ranke MB. Isolated GH deficiency with dominant inheritance: new mutations, new insights. Journal of Clinical Endocrinology and Metabolism 200186 3877-3881.

16 Chen EY, Liao YC, Smith DH, Barerra-Saldana HA, Gelinas RE \& Seeburg PH. The human growth hormone locus: nucleotide sequence, biology, and evolution. Genomics 19894 479-487.

17 Mullis PE, Robinson ICA, Salemi S, Eblé A, Besson A, Vuissoz JM, Deladoëy J, Simon D, Czernichow P \& Binder G. Isolated autosomal dominant growth hormone deficiency (IGHD II): an evolving pituitary deficit? A multi-center follow-up study. Journal of Clinical Endocrinology and Metabolism 200590 2089-2096.

18 McGuinness L, Magoulas C, Sesay AK, Mathers K, Carmignac D, Manneville JB, Christian H, Phillips JA III \& Robinson IC. Autosomal dominant growth hormone deficiency disrupts secretory vesicles in vitro and in vivo in transgenic mice. Endocrinology 2003 $144720-731$.

19 Ryther RC, Flynt AS, Harris BD, Phillips JA III \& Patton JG. GH1 splicing is regulated by multiple enhancers whose mutation produces a dominant-negative GH isoform that can be degraded by allele-specific siRNA. Endocrinology 2004145 2988-2996.

20 Arvan P \& Castle D. Sorting and storage during secretory granule biogenesis: looking backward and looking forward. Biochemical Journal 1998332 593-610.

21 Dannies PS. Protein hormone storage in secretory granules: mechanisms for concentration and sorting. Endocrine Review $1999203-21$.

22 Halban PA \& Irminger JC. Sorting and processing of secretory proteins. Biochemical Journal 1994299 1-18.

23 Ranke MB. Diagnosis of growth hormone deficiency and growth hormone stimulation tests. In Diagnostics of Endocrine Function in Children and Adolescents, revised and extended edn 3, pp 107-128. Ed. MB Ranke. Basel: Karger, 2003.

24 Greulich WW, Pyle SI. Radiographic Atlas of Skeletal Development of the Hand and Wrist. Stanford California: Stanford University Press, 1959.

25 GH Research Society, Consensus guidelines for the diagnosis and treatment of growth hormone (GH) deficiency in childhood and adolescence: summary statement of the GH Research Society. Journal of Clinical Endocrinology and Metabolism 200085 3990-3993.

26 Blum WF, Albertsson-Wikland K, Rosberg S \& Ranke MB. Serum levels of insulin-like growth factor I (IGF-I) and IGF binding protein 3 reflect spontaneous growth hormone secretion. Journal of Clinical Endocrinology and Metabolism 199376 1610-1616.

27 Argyropoulou M, Perignon F, Brunelle F, Brauner R \& Rappaport R. Height of normal pituitary gland as a function of age evaluated by magnetic resonance imaging in children. Pediatric Radiology 199121 247-249.

28 Argyropoulou M, Perignon F, Brauner R \& Brunelle F. Magnetic resonance imaging in the diagnosis of growth hormone deficiency. Journal of Pediatrics 1992120 886-891.

29 Tsunoda A, Okuda O \& Sato K. MR height of the pituitary gland as a function of age and sex: especially physiological hypertrophy in adolescence and in climacterium. American Journal of Neuroradiology $199718551-554$.

30 Nauseef WM, McCormick SJ \& Clark RA. Calreticulin functions as a molecular chaperone in the biosynthesis of myeloperoxidase. Biochemical Journal $19952704741-4747$.

31 Oprins A, Duden R, Kreis TE, Geuze HJ \& Slot JW. Beta-COP localizes mainly to the cis-Golgi side in exocrine pancreas. Journal of Cell Biology 1993121 49-59.

32 Matteoli M, Takei K, Cameron R, Hurlbut P, Johnston PA, Sudhof TC, Jahn R \& De Camilli P. Association of Rab3A with synaptic vesicles at late stages of the secretory pathway. Journal of Cell Biology 1991115 625-633. 
33 Costes S, Cho E, Catalfamo M, Karpova T, McNally J, Henkart P \& Lockett S. Automatic 3D detection and quantification of co-localization. Microscopy and Microanalysis 20028 1040-1041.

34 Marino R, Chaler E, Warman M, Ciaccio M, Berensztein E, Rivarola MA \& Belgorosky A. The serum growth hormone $(\mathrm{GH})$ response to provocative tests is dependent on type of assay in autosomal dominant isolated $\mathrm{GH}$ deficiency because of an Arg183His (R183H) GH-1 gene mutation. Clinical Chemistry $2003491002-1005$.

35 Besson A, Salemi S, Deladoëy J, Vuissoz JM, Eblé A, Bidlingmaier M, Bürgi S, Honegger U, Flück C \& Mullis PE. Short stature caused by a biologically inactive mutant growth hormone (GH-C53S). Journal of Clinical Endocrinology and Metabolism 200590 2493-2499.

36 Strasburger CJ. Wu Z, Pflaum CD \& Dressendorfer RA. Immunofunctional assay of human growth hormone (hGH) in serum: a possible consensus for quantitative hGH measurement. Journal of Clinical Endocrinology and Metabolism 199681 2613-2620.

37 Deladoëy J, Stocker P \& Mullis PE. Autosomal dominant GH deficiency due to an Arg183His GH-1 gene mutation: clinical and molecular evidence of impaired regulated GH secretion. Journal of Clinical Endocrinology and Metabolism 2001863941 -3947.

38 Zhu YL, Conway-Campell B, Waters MJ \& Dannies PS. Prolonged retention after aggregation into secretory granules of human R183H-growth hormone $(\mathrm{GH})$, a mutant that causes autosomal dominant GH deficiency type II. Endocrinology $20021434243-4248$.

39 Lee MS, Zhu YL, Chang JE \& Dannies PS. Acquisition of Lubrol insolubility, a common step for growth hormone and prolactin in the secretory pathway of neuroendocrine cells. Journal of Biological Chemistry 2001276 715-721.

40 Chanat E \& Huttner WB. Milieu-induced, selective aggregation of regulated secretory proteins in the trans-Golgi network. Journal of Cell Biology 1991115 1505-1519.

41 Yoo SH. pH- and Ca-dependent aggregation property of secretory vesicle matrix proteins and the potential role of chromogranins A and B in secretory vesicle biogenesis. Journal of Biological Chemistry $19962711558-1565$.

42 Castle AM, Schwarzbauer JE, Wright RL \& Castle JD. Differential targeting of recombinant fibronectins in AtT-20 cells based on their efficiency of aggregation. Journal of Cell Science 1995108 3827-3837.

43 Cunningham BC, Mulkerrin MG \& Wells JA. Dimerization of human growth hormone by zinc. Science 1991253 545-548.

44 Creemers JWM, Usac EF, Bright NA, Van De Loo JW, Jansen E, Van De Ven WJM \& Hutton JC. Identification of a transferable sorting domain for the regulated pathway in the prohormone convertase PC2. Journal of Biological Chemistry $199627125284-25291$.

45 Mouchantaf R, Kumar U, Sulea T \& Patel YC. A conserved alphahelix at the amino terminus of prosomatostatin serves as a sorting signal for the regulated secretory pathway. Journal of Biological Chemistry $200127626308-26316$.

46 Moore HH \& Kelly RB. Re-routing of a secretory protein by fusion with human growth hormone sequences. Nature $1986321443-446$.

47 Yoo SH. pH-dependent interaction of chromogranin A with integral membrane proteins of secretory vesicle including 260-kDa protein reactive to inositol 1,4,5-triphosphate receptor antibody. Journal of Biological Chemistry 1994269 12001-12006.

48 Cool DR, Normant E, Shen FS, Chen HC, Pannell L, Zhang Y \& Loh YP. Carboxypeptidase E is a regulated secretory pathway sorting receptor: genetic obliteration leads to endocrine disorders in Cpe-fat mice. Cell 199788 73-84.

49 Baertschi AJ, Monnier D, Schmidt U, Levitan ES, Fakan S \& Roatti A. Acid prohormone sequence determines size, shape, and docking of secretory vesicles in atrial myocytes. Circulation Research 200189 E23-E29.

Received 7 July 2005

Accepted 2 September 2005 